Ind. Health, 1973, 11, 43.

\title{
SIGNIFICANCE OF SERUM CALCIUM, INORGANIC PHOSPHATES AND ALKALINE PHOSPHATASE IN EXPERIMENTAL MANGANESE TOXICITY
}

\author{
Satya V. Chandra, Z. Imam and Neeti Nagar \\ Industrial Toxicology Research Centre, Lucknow, U.P., India
}

(Received January 20, 1973)

\begin{abstract}
Rabbits were injected intratracheally manganese dioxide $(400 \mathrm{mg} / \mathrm{kg})$. Serum calcium, inorganic phosphates and alkaline phosphatase levels were determined at the interval of 60 days over a period of 240 days. Simultaneously histological studies were carried out in parathyroids, bones and kidneys. A significant decrease in the levels of serum alkaline phosphatase, inorganic phosphates and an increase in calcium was noted at 180 days. These biochemical alterations occured at a much earlier stage than the development of symptoms of manganese encephalopathy which are of great significance to detect early toxicity.
\end{abstract}

Experimental studies on manganese toxicity from our laboratory have been reported earlier. ${ }^{1 \sim 5)}$ The present investigation deals with further attempts which have been made to detect manganese toxicity earlier than the appearance of neurological manifestations. Preliminary observations of a rise in the level of serum calcium in parenterally manganese administered animals led us to study the significance of serum calcium, inorganic phosphates and alkaline phosphatase. It was thought worthwhile to study also the morphological changes in parathyroids, bones and kidneys, the organs of importance in the metabolism of blood calcium and phosphates.

\section{Materials AND Methods}

Male rabbits of I.T.R.C. colony weighing on an average $1.5 \mathrm{~kg}$ were used in the experiments. The animals housed singly in cages, were given standard diet (Hindustan Levers Ltd., India) and water ad libitum. Group I consisting of 18 rabbits kept as control were injected intratracheally under ether anaesthesia with $1.5 \mathrm{ml}$ physiological saline and group II consisting of 30 animals were injected intratracheally under ether anaesthesia with manganese dioxide dust $(400 \mathrm{mg} / \mathrm{kg}$ ) of particle size below $5 \mu$ suspended in $1.5 \mathrm{ml}$ physiological saline. A batch of 3 animals from group I and 6 from group II were sacrificed at the interval of 60 days upto a period of 240 days. Their blood for biochemical estimations was collected from cardiac puncture and serum was separated. Kidneys and parathyroids were 


\section{S. V. CHANDRA, Z. IMAM AND N. NAGAR}

dissected out and put in buffered formal saline for routine histology. Long bones were dissected and cleaned, after usual decalcification process by the method of Pearse $^{6)}$ processed for routine histology.

Estimations of serum calcium, inorganic phosphates and alkaline phosphatase were carried out by the method of Clark and Collip, ${ }^{7)}$ Fiske and Subbarow ${ }^{8)}$ and King and Armstrong ${ }^{9)}$ respectively.

\section{RESULTS}

\section{Blood chemistry}

In our experiments the serum calcium level in control animals was reasonably constant. In 18 control animals the mean serum calcium concentration and standard deviation was $7.43 \pm 0.495 \mathrm{mg} / 100 \mathrm{ml}$. In rabbits which were injected $\mathrm{MnO}_{2}$ intratracheally the level of serum calcium remained within normal limits upto 120 days, at 180 days the mean serum calcium level $(9.33 \pm 0.244)$ was significantly greater than that in the controls $(\mathrm{p}<0.001)$. Increase in the level was also noted $(10.2 \pm 0.368)$ at 240 days.

The mean concentration of inorganic phosphates in serum in 18 control rabbits was $4.83 \pm 0.309 \mathrm{mg} / 100 \mathrm{ml}$. There was significant decrease $(3.84 \pm 0.134)$ in the level of inorganic phosphates in manganese treated animals at 120 days and there was gradual lowering in the level at 180 and 240 days.

The mean activity with standard deviation of alkaline phosphatase in 18 control animals was $6.56 \pm 1.18 \mathrm{~K}$. A. units. The level of this enzyme showed significant decrease even at 60 days in manganese treated animals, the values showed a further decline during later periods of experimentation (Table 1).

Table 1. Serum calcium, inorganic phosphates and alkaline phosphatase in manganese toxicity. The mean levels \pm S. E.M. of (n) determinations are shown.

\begin{tabular}{|c|c|c|c|c|c|}
\hline \multirow{2}{*}{ Values in serum } & \multirow{2}{*}{$\begin{array}{l}\text { Control } \\
\text { rabbits }\end{array}$} & \multicolumn{4}{|c|}{$\begin{array}{l}\text { Rabbits inoculated intratracheally with } \mathrm{MnO}_{2} \\
\qquad(400 \mathrm{mg} / \mathrm{kg})\end{array}$} \\
\hline & & 60 days & 120 days & 180 days & 240 days \\
\hline Calcium $\mathrm{mg} / 100 \mathrm{ml}$ & $\begin{array}{l}7.43(18) \\
\pm 0.495\end{array}$ & $\begin{array}{l}8.44(6) \\
\pm 0.150\end{array}$ & $\begin{array}{l}8.40(6) \\
\pm 0.193\end{array}$ & $\begin{array}{l}9.33(6) \dagger \\
\pm 0.244\end{array}$ & $\begin{array}{l}10.2(6)^{\dagger} \\
\pm 0.368\end{array}$ \\
\hline $\begin{array}{l}\text { Inorganic phosphates } \\
\mathrm{mg} / 100 \mathrm{ml}\end{array}$ & $\begin{array}{l}4.83(18) \\
\pm 0.309\end{array}$ & $\begin{array}{l}4.15(6) \\
\pm 0.126\end{array}$ & $\begin{array}{l}3.84(6) \dagger \\
\pm 0.134\end{array}$ & $\begin{array}{l}3.68(6)^{\dagger} \\
\pm 0.163\end{array}$ & $\begin{array}{l}3.17(6){ }^{\dagger} \\
\pm 0.424\end{array}$ \\
\hline $\begin{array}{l}\text { Alkaline phosphatase } \\
\text { K. A. units }\end{array}$ & $\begin{array}{l}6.56(18) \\
\pm 1.18\end{array}$ & $\begin{array}{l}3.48(6)^{\dagger} \\
\pm 0.451\end{array}$ & $\begin{array}{l}2.96(6) \dagger \\
\pm 0.302\end{array}$ & $\begin{array}{l}2.13(6) \dagger \\
\pm 0.927\end{array}$ & $\begin{array}{l}3.00(6){ }^{\dagger} \\
\pm 0.451\end{array}$ \\
\hline
\end{tabular}

$\dagger$ Significantly differed from control $\mathrm{p}<0.001$.

\section{Histopathology}

Parathyroids and bones. No gross and microscopic abnormality was observed in para thyroids and bones in both the groups. There was no evidence of hyperplasia of parathyroid glands as evidenced from the mean weight of ane gland in both the 


\section{EXPERIMENTAL MANGANESE POISONING}

groups which was $0.3 \mathrm{mg}$. No evidence of osteoporosis was seen in the bones.

Kidneys. Grossly, the kidneys of control animals were normal in size, weight and colour throughout the experiment. Kidneys of experimental animals at 60 days were swollen and congested, on sectioning the capsule stripped off easily, the corticomedullary junction was distinct, medulla was hyperemic and reddish brown in colour. At 120 and 180 days kidneys were congested. There was no other significant alteration. At 240 days very fine granularity was observed on the surface of the kidneys and at places capsule was thickened and adherent to the surface. The corticomedullary junction was accentuated and medulla was reddish brown.

On microscopic examination the kidneys of control animals did not show any abnormality during the course of the experiment. Sections from the kidneys of manganese inoculated animals at 60 days showed marked congestion and small haemorrhages in the interstitial tissue. Capillary loops of glomeruli were markedly congested and red blood cells were seen lying free in Bowmans space. Marked necrosis of mainly proximal tubular epithelial cells was seen with nuclear pyknosis or karyolysis, markedly eosinophilic cytoplasm and cellular exfoliation (Fig. 1).

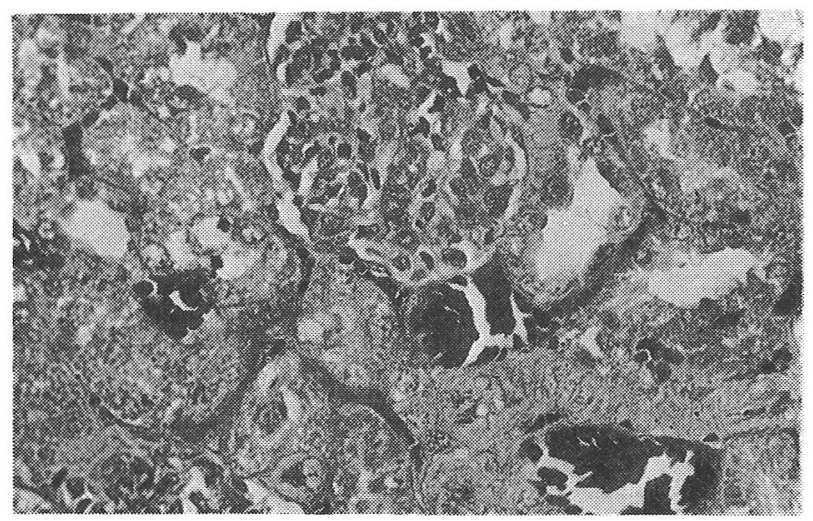

Fig. 1. Section from kidney of a rabbit 60 days after intratracheal inoculation of $\mathrm{MnO}_{2}(400 \mathrm{mg} / \mathrm{kg})$ showing marked congestion and necrosis of tubular epithelial cells.

Haematoxylin \& Eosin $\times 630$.

At 120 days congestion was much less than seen at 60 days. Necrosis of proximal as well as distal convoluted tubules was seen, cellular outlines were indistinct and there was marked vacuolation of the cytoplasm, cellular debris and red blood cells were seen lying in the tubular lumen. Further at 180 days there were focal necrotic areas and distorted tubules in the cortex with collection of inflammatory cells and young fibroblasts. Glomoruli did not show any abnormality excepting at few places one or two glomeruli showed complete obliteration of Bowmans space. 


\section{S. V. CHANDRA, Z. IMAM AND N. NAGAR}

At 240 days capsule was slightly thickened and fibrous bands were extending from the capsule deep down into the cortex. In the cortex at places fibrous tissue replaced the degenerated tubules near the glomeruli. Medulla was congested and focal collection of inflammatory cells mainly lymphocytes was seen in the interstitial spaces.

\section{Comments}

Intratracheal administration of manganese dioxide in rabbits has produced significant alterations in the level of serum calcium, inorganic phosphates and alkaline phosphatase. Alkaline phosphatase activity was decreased as early as 60 days, serum calcium showed an increase at 180 days while neurological manifestations occur after 18 to 24 months in rabbits under similar condition. ${ }^{4}$ Therefore, these tests appear to be of significance in the diagnosis of early manganese toxicity. The present report is in agreement with the normal values of calcium and inorganic phosphates reported by Cole and Rapport, ${ }^{10)}$ show mean values of serum calcium and inorganic phosphates in rabbits as $7.43 \mathrm{mg}$ and $4.83 \mathrm{mg} / 100 \mathrm{ml}$ respectively. In manganese inoculated animals serum calcium was increased to $9.33 \mathrm{mg} /$ $100 \mathrm{ml}$ at 180 days, inorganic phosphates was lowered to $3.84 \mathrm{mg} / 100 \mathrm{ml}$ at 120 days and serum alkaline phosphatase also significantly lowered at 60 days.

The mechanism of hypercalcaemia and hypophosphataemia in manganese toxicity is not clear although Suzuki et al. ${ }^{11)}$ suggested that it may be of some diagnostic value. It appears unlikely that hypercalcaemia was due to bone changes because there was no histological evidence of rarification of bones. However, the possibility of calcium mobilising ability of manganese can not be ruled out as bones may not show morphological alterations in such an early stage. Second possibility of such changes may be due to hyperactivity of parathyroids but no such evidence was available from histology. The low levels of alkaline phosphatase does not favour the possibility of parathyroids hyperactivity. The third possibility for hypercalcaemia and hypophosphataemia in manganese intoxication may be the role of gastrointestinal tract in absorption of these substances. It has been shown that gastrointestinal tract is the major route of entry for the manganese into the body even when it is first inhaled. ${ }^{12)}$ Further, metals like iron, beryllium, lead, manganese, aluminium and strontium form insoluble phosphates in the gastrointestinal tract and interfere with absorption of phosphates. ${ }^{13)}$ Therefore, the presence of excess of manganese in gastrointestinal tract may interfere with phosphate absorption which resulted in hypophosphataemia. At the same time manganese may also alter the $\mathrm{pH}$ of gastrointestinal tract favouring the absorption of calcium leading to hypercalcaemia.

The renal damage observed in the present experiment may cause increased phosphate diuresis leading to hypophosphataemia.

The serum alkaline phosphatase was noted almost 50\% lower much earlier 


\section{EXPERIMENTAL MANGANESE POISONING}

than the changes in serum calcium and inorganic phosphates. Further work is in progress to explain this mechanism.

\section{AcKNOWLEDgEMENTS}

The authors are grateful to Dr. S. H. Zaidi, Director, I.T.R.C. for his guidance and keen interest in this work. We would like to acknowledge the valuable technical assistance of Shri I. Ansari.

\section{REFERENCES}

1) Chandra, S. V. and Srivastava, S. P. (1970). Acta Pharmacol. Toxicol., 28, 177.

2) Chandra, S. V. and Sur, R. N. (1970). Environ. Res., 3, 417.

3) Mustafa, S. J. and Chandra, S. V. (1971). J. Neurochem., 18, 931.

4) Mustafa, S. J. and Chandra, S. V. (1972). Arch. Toxikol., 28, 277.

5) Chandra, S. V. (1972). Arch. Toxikol., 29, 29.

6) Pearse, A.G.E. (1968). Histochemistry; Theoretical and Applied, 3rd Ed, p. 579. Churchill Livingstone, London.

7) Oser, B.L. (1965). Hawk's Physiological Chemistry, p. 1133. McGraw Hill Book Company, New York.

8) Oser, B. L. (1965). Hawk's Physiological Chemistry, p. 1113. McGraw Hill Book Company, New York.

9) Wooton, I. D.P. (1964). Micro-Analysis in Medical Biochemistry, p. 101. J. \& A. Churchill Ltd., London.

10) Long, Cyril. (1961). Biochemists' Handbook, pp. 873, 876. E and F. N. Spon Ltd., London.

11) Suzuki, Y. (1960). Tokushima J. Exptl. Med., 7, 124.

12) Mena, I., Horiuchi, K., Burke, K. and Cotzias, G.C. (1969). Neurology, 19, 1000.

13) Cantarow, A. and Trumper, M. (1965). Clinical Biochemistry, p. 218. W. B. Saunders Company, Philadelphia. 